\title{
Assessment of Antoni Gaudi's Design Approach on the Concept of Biophilia: Case of Casa Battlo
}

\author{
Gizem Özer Baş ${ }^{1}$ I Melih Kurnalı ${ }^{2}$
}

\author{
${ }^{1}$ Teaching Assistant Dr., Manisa \\ Celal Bayar University, \\ Manisa/Turkey \\ ORCID: 0000-0002-4565-1726 \\ E-Mail: \\ gizemozergizem@gmail.com \\ 2 Asisst. Prof. Dr., Konya \\ Technical University, \\ Konya/Turkey \\ ORCID: 0000-0003-0267-9101 \\ E-Mail \\ melih56kurnali@gmail.com
}

Corresponding Author:

Gizem Özer Baş

January 2022

Volume:19

Issue: 45

DOI: $10.26466 / /$ opusjsr.1062892

Citation

Özer Baş, G. and Kurnall, M (2022). Assessment of Antoni

Gaudi's Design approach on the concept of biophilia: Case of

Casa Battlo . OPUS- Journal of Society Research, 19(45), 143-157.

\begin{abstract}
With the modernism movement, the diversification of design approaches has accelerated and, many methods focused on the solution of new problems have emerged. The design approaches, which move away from natural life and aim at the mechanical purposes of the function, have increased the longing of the people living in the cities for nature. In this sense, the biophilic design emerges as a new concept and aims to transfer nature to the building design in a direct and non-artificial way. The buildings of Antoni Gaudi, who had a design understanding far beyond his age, presented the reflections of nature in his unique ways. At this point, if Gaudi's approach to nature is questioned, his place in biophilic design, one of today's concepts, is a serious research topic. To what extent does the biophilic approach, which seeks to bring the new and modern together with nature, takes place in Gaudi's designs, which embody nature in a plastic and concrete sense. To what extent does the biophilic approach, which seeks to bring the new and modern together with nature, take place in Gaudi designs, which include nature in a plastic and concrete sense? The study aims to evaluate Casa Battlo, one of the Gaudi designs, through biophilic design criteria. For this purpose, biophilic design, Antoni Gaudi and his Works examined. The biophilic design criteria obtained because of the examination were used to evaluate Casa Battlo. Gaudi's Casa Battlo shows how the conceptually new term biophilia is at the core of this building. In this sense, the study shows how the conceptual essence of biophilia works like a spirit from the past that makes the structure permanent and unforgettable.
\end{abstract}

Key Words: Biophilic Design, Architecture, Gaudi, Casa Battlo, Design.

Öz

Modernizm akımı ile tasarım anlayışlarındaki çeşitlenme hızlanmıştır. Buna bağh olarak ortaya çıkan problemlerin çözümüne odaklanan birçok yaklaşım türemiştir. Doğal yaşantıdan uzaklaşan, işlevin mekanik odağındaki tasarım yaklaşımları, kentlerde yaşayanların doğala olan özlemini arttırmıştır. Biyofilik tasarım bu anlamda yeni bir kavram olarak ortaya çıarak yapı tasarımına doğanın direkt aktarımını hedeflemektedir. Çă̆ının çok ötesinde bir tasarım anlayışına sahip olan Antoni Gaudi'nin yapıları doğanın yansımalarını kendine has yöntemlerle sunmaktadır. Bu noktada Gaudi'nin doğala olan yaklaşımı sorgulanırsa, günümüz kavramlarından biyofilik tasarımdaki yeri önemli bir araştırma konusudur. Doğayı plastik ve somut anlamda içine alan Gaudi tasarımlarında; yeni ve modern olanı doğayla buluşturmayı esas alan biyofilik yaklaşımın ne kadar ve ne biçimde yer aldığı çalışmanın konusunu oluşturmaktadır. Çalışma, Gaudi tasarımlarından Casa Battlo'nun biyofilik tasarım ölçütleri üzerinden değerlendirilmesini hedeflemektedir. Bu amaçla biyofilik tasarım, Antoni Gaudi ve Eserleri incelenmiştir. İnceleme sonucu elde edilen biyofilik tasarım kriterleri Casa Battlo'yu değerlendirmede kullanılmıştır. Çă̆ının ilerisindeki anlayışı ile Gaudi'nin Casa Battlo'su, kavramsal olarak yeni bir terim olan biyofiliğin, seneler önce inşa edilmiş bu yapının özünde nasıl bulunduğunu göstermektedir. Bu anlamda çalışma, biyofiliğin kavramsal özünün geçmişten gelen ve yapının kahıcı ve unutulmaz olmasın sağlayan bir tin gibi nasıl işlediğini göstermektedir.

Anahtar Kelimeler: Biyofilik Tasarm, Mimarlk, Gaudi, Casa Battlo, Tasarm. 


\section{Introduction}

\section{Human, Nature and Design}

Man is a being who is both a part of nature and cannot adapt to nature exactly. Although human belongs to nature, the need for protection and shelter from nature requires the built environment and its design. The word design is defined in three senses in the dictionary. Its first meaning is "the work of designing or the designed form, imagination." The second meaning is called 'plan' and 'project'. The third is "a copy of an object or event that has been perceived before, which is subsequently revealed in consciousness" (Parlatir et al., 1988, p.2143). Nature plays a central role for man when it comes to a new design (Antoniades, 1992, p.18).

Vitruvius supported this with the imitative and readiness to learn of ancient people, and the production of structures that started by imitating swallows' nests in nature (Vitrivius, 2005, p.27). In the following process, design has continued its development through the inspiration of people from each other. However, architectural historians and designers alike agree that design emerges from nature.

In this context, design approaches can be defined as mental production methods with many features that are very diversified due to their structure and come across with very different qualities. Considering the connection of man with nature, the definitions of the concept of design and their relationship with each other; It is clear that approaches based on nature for design have a wide place in the design literature.

As in all disciplines that require design, naturebased approaches have been frequently preferred throughout history and have continued to be used even though they have changed and transformed as a method.

Throughout history, civilizations have been inspired by nature while building their structures, and they have used this concept in their designs centuries before the term biophilia entered the literature. The remains in Göbeklitepe, the oldest known settlement, which is 12 thousand years old, show that hunter-gatherer people lived in a scattered way before they settled down, but they gathered around the fire (which is a part of nature) in times of danger (Schmidt, 2010, p.241). Like the animal figures carved into the stones at Göbeklitepe, the Egyptian columns inspired by palm and lotus trees or the herbal ornaments of Greek temples are the oldest examples (Ramzy, 2015, p.259).

Ornaments were known as indirect imitations of nature and used used in architecture. For instance, Mycenean palaces were decorated with marine motifs and Corinthian columns were carved to resemble leaves and floral patterns (Rian \& Sassone, 2014, p.302).

When it comes to recent dates, the situation has not changed. While technological developments and the industrial age continued to progress rapidly in the 19th century, it is argued that architectural works still imitate old styles such as art nouveau, decorative movements and so on. Art neuveau and baroque styles feature abundant curvilinear lines, organic motifs and ornaments, with a passion for biodynamics. Advocates of new architectural principles have also recently advocated taking inspiration from natural shapes and processes (Gündüz, 2019, p.20).

The rapid progress of the industrial age in the recent past has damaged the nature and after a while, ecological design, green design, sustainable design, and similar approaches have emerged. Today, such as regenerative design, organic design, biomimicry, which have deeper ecological goals; Approaches that integrate human with nature and also away from harming nature have emerged (Gündüz, 2019, p.20). To summarize, when these approaches are examined and compared separately, it is seen that although there are design approaches that take nature as a model in architectural space design and production, there are different objectives and guides.

In short, design approaches throughout history have reflected the effects of nature brought by the period. Design approaches, shaped in various ways, have been used, sometimes to use nature analogically, and sometimes to ensure sustainability in terms of energy consumption. 
Today, making people feel good through nature, with the historical interiority they bring, expresses the main approach of design spatially. It is necessary to explain in detail the biophilic design approach that assembles this meaning.

\section{Biophilic Design}

Biophilia, which means love of life, is semantically formed by the combination of the word's bio (related to life and living things) and philia (tendency or love for something). In this perspective, it was first used in the literature by the German sociopsychologist Erich Fromm in the late 1970s to express the love for life or living things (Şenozan, 2018, p.25). Fromm's book titled "The Source of Love and Violence" states, "In the field of life, an effect can only be achieved with life forces such as love and stimulation. Life can only be perceived in an individual, in a bird, in a flower, with individual examples" (Fromm, 1979, p.56). Wilson, an evolutionary theorist and biologist, defined this concept in a different descriptive way in 1984 as "man's innate tendency towards life and life-like processes" (Wilson, 1984, p.3).

Wilson expanded this concept and tried to express the bond of man to nature in a different way. In fact, it can be seen by a biologist trying to express a commitment or passion for the continuity of the species.

One of the examples that can be given for the continuity of the species is that adult mammals find baby mammals attractive. The facial features and body lines of young individuals and babies are described as more beautiful for the species. With this positive perspective, babies are protected more, and the continuity of the species is ensured (https://tr.wikipedia.org/wiki/Biyofili_hipotezi). With this aspect, this hypothesis also expresses Wilson's support for the continuity of the species and evolutionary theory.

Orr (2002) states in his book 'The Nature of Design' that spaces with vital 'things' are more harmonious for people. The fact that the spaces with trees, flowers, water, birds or sunlight from nature feel much better makes the biophilic design hypothesis meaningful in spatial structuring (Orr, 2002, p.16).
In a similar way in terms of environmental and vitality, this hypothesis suggests that people's love for natural life keeps them alive, as they feed their pets, grow plants, visit zoos, organize organizations with green and natural life, and even risk their own life to save an endangered creature. explains it in terms of retention (https://tr.wikipedia.org/wiki/Biyofili hipotezi).

This concept, in its general meaning, draws attention to the need for human interaction with natural elements.

In this sense, the need to explain the architectural approach and the concept of biophilia in the context of the spaces that make up the human environment is to underline the fact that humans will find the feeling of peace and security they need in nature itself (Bayraktaroğlu, 2013, p.46). The nature-based features of biophilia design include: locality, texture, balance and continuity (Bayraktaroğlu, 2013, p.47).

The article "Building Biophilia: Connecting People and Nature" published in 2001 by Heerwagen \& Hase, who was the first to study biophilic design elements, spatially: a list of models such as broad-minded landscape, shelter, attraction, complexity and order, together with defining spatial environmental preferences, biophilic design started to define it (Ünlü, 2017, p.61). Although it was defined by many researchers in the following years, the most known and current content is the studies by Kellert and Wilson.

The concept of biophilia was carried to the discipline of architecture by Kellert in the sense of 'Biophilia Design'. Researchers incorporated their ideas about biophilia into architectural design with their work called 'Building for Life' and the concept of 'Biophilic Design' was defined by them; the elaboration of it was formed by another work of 2008 named 'Biophilic Design'.

Biophilic design is about creating a natural and biologically feel-good habitat for humans in the spatially built close environment. As with all living things, humans are also ecologically interconnected with nature, which is their immediate environment. people are not artificial; its connection to nature is biological and mental in its own structure. Biophilic design aims to meet the 
inner harmony associated with nature in the built environment and spaces and to improve the physical and mental health of people (Kellert \& Calabrese, 2015, p.21). Numerous scientific studies also support that (Figure 1).

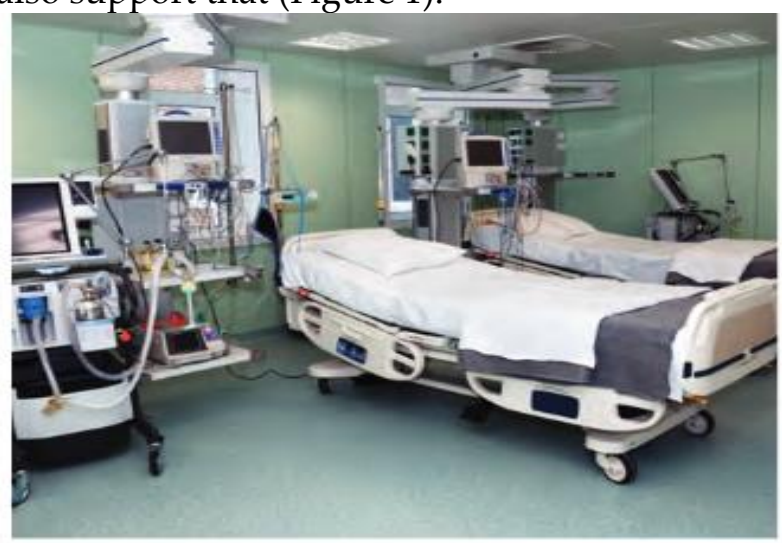

MANY HOSPITAL ROOMS ARE DOMINATED BY TECHNOLOGY AND DEVOID OF ANY CONNECTION TO NATURE.

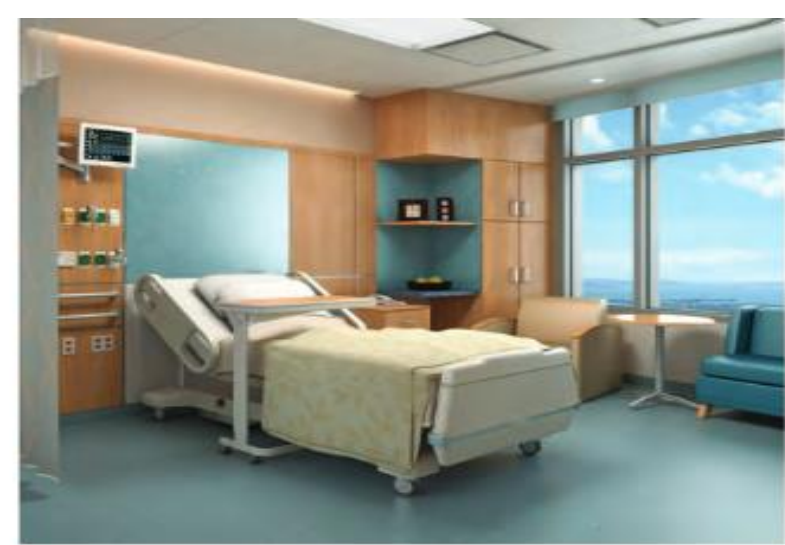

RESEARCH HAS INDICATED A VIEW OF NATURE CAN ENHANCE RECOVERY FROM ILLNESS AND SURGERY, AND REDUCE THE NEED FOR POTENT PAIN MEDICATION.

Figure 1. Hospital room sample- biophilic design (Kellert \& Calabrese, 2015, p.4)

Architecturally, biophilic design has been discussed not only by Kellert but also by many researchers. However, the most up-to-date model of today's classifications and the intersection of common titles is used as the most reliable source for biophilic design within the scope of the methodology that Kellert has developed and simplified over the years. Biophilic design concept consists of three phases (Figure 2).

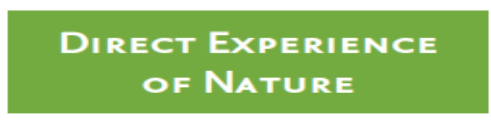

- Light

- Air

- Water

- Plants

- Animals

- Weather

- Natural landscapes and ecosystems

- Fire

\section{INDIRECT EXPERIENCE OF NATURE}

- Images of nature

- Natural materials

- Natural colors

- Simulating natural light and air

- Naturalistic shapes and forms

- Evoking nature

- Information richness

- Age, change, and the patina of time

- Natural geometries

- Biomimicry
EXPERIENCE OF Space and Place

- Prospect and refuge

- Organized complexity

- Integration of parts to wholes

- Transitional spaces

- Mobility and wayfinding

- Cultural and ecological attachment to place

Figure 2. Three phases of biophilic design (Kellert $\mathcal{E}$ Calabrese, 2015, p.10)

To understand the Casa Batllo better, which will be examined within the scope of biophilic design, it would be appropriate to examine the building's designer, the architect. 


\section{Antoni Gaudí i Cornet}

The architect, known by his short name and full name Antoni Gaudí i Cornet, was born on June 25, 1852 in Reus, the capital of the Baix Camp region in the south of Catalonia. Gaudi's older sister Rosa, one of three siblings, lives modestly in the centre of Reus with her brother Francesca and her parents. Gaudi, who was an active entrepreneur at an early age, moved to Barcelona in 1868 with his brother, who was studying medicine, to complete secondary school (Dosde, 2016, p.20).

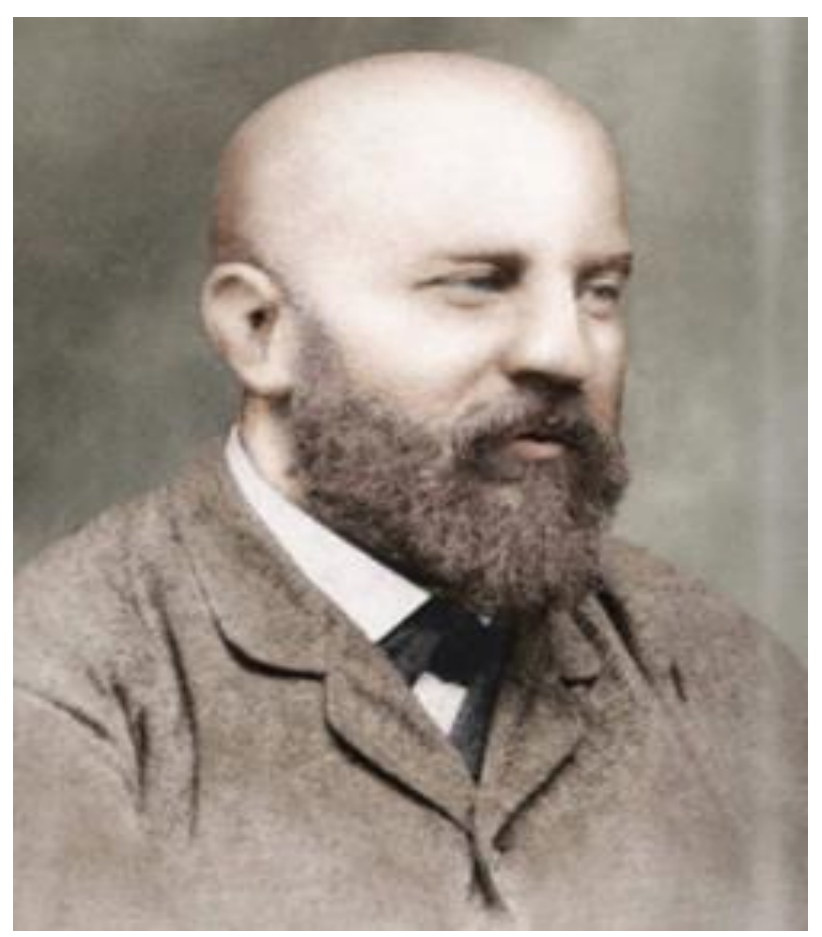

Figure 3. Antoni Gaudí i Cornet (36 years old) (Dosde, 2016, p.62)

After coming to Barcelona, Antoni Gaudi started the academy of sciences in 1869 , but his transition to his main profession started with his entry to the faculty of architecture in 1873 (Yakın, 2016, p.12).

In 1875, he was successful in his exam with the door project he designed for a cemetery entrance and was awarded "the extraordinary jewellery" in his faculty. Afterwards, Gaudi's works, the atmosphere he created and felt in his drawings not only revealed the excitement in the field of architecture, but also revealed his strong intelligence. Professors could not remain indifferent to this situation, and they were conflicted about whether he was a genius or a madman. Gaudi was influenced by the ideas of the French architect Eugene Viollet-le-Duc and the English thinker John Ruskin, who said that "ornamentation is the source of architecture". In time, it went beyond the dominant historical styles of the 19th century and created its own unclassifiable aesthetic. The styles that Gaudi began to be influenced in his student life developed him over time and formed the building blocks of his professional life (Yakın, 2016, p.13).

Gaudi was made a quick introduction to his profession and career, started to work with architects such as Josep Fontserè, Francisco de Paula del Villar and Joan Martorell. However, as his mother and brother were negatively affected by the death of his mother and brother in 1876, and a few years later, his sister's death, his progress in his profession slowed down for a certain period (Dosde, 2016, p.21).

In 1878 Gaudi graduated as an architect and set up his office on Calle del Call in Barcelona's old Jewish quarter. It was there that he began work on his first commissions, such as facilities for a cooperative association, some streetlights for Barcelona Plaza Real, and a showcase for the prestigious Comella glove shop. This last work caught the attention of powerful Barcelona industrial magnate Eusebi Güell i Bacigalupi, who would soon become the architect's main patron. Thanks to his involvement in Barcelona's most distinguished intellectual circles, Gaudí was able to take part in architectural projects that enabled him to leave his poor student years behind (Dosde, 2016, p.27). 


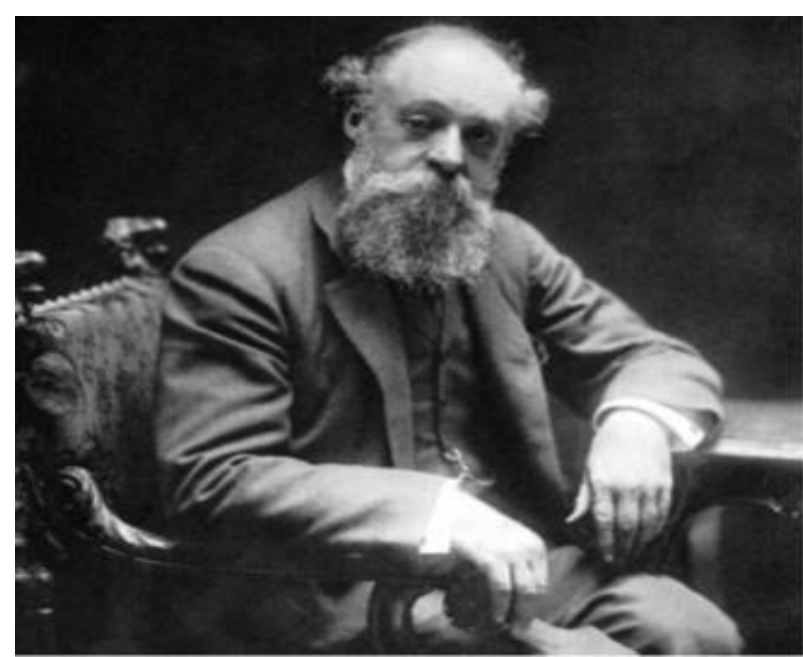

Figure 4. Catalan architect Gaudi

(https://www.dosde.com/discover/en/antoni-gaudisbiography/)

Between 1896 and 1900, when the reflections of other styles were clearly seen, motifs and floral ornaments were at the forefront in the $\mathrm{Neo}$ Baroque style. Antoni Gaudi, who said, "We should not imitate or repeat Gothic, just continue it," created the first examples of this trend by using colorful surfaces, wavy forms, abundant decoration and organic motifs in his works with his unique style. Bent and curved striped patterns were used as ornamental elements throughout the buildings, which are considered as a synthesis of Gothic architecture and Catalan architecture.

With this image and line, he decides to design an unusual building for a customer who reaches him one day. He interpreted the Art nouveau style in his own way by making a fairy-tale expression in both its decorations and details. Thereupon, Casa Batlló was built on a street with adjoining buildings, attracting the attention of the whole world and hosting millions of tourists every year (Yakin, 2016, p. 16).

Although the simplification seen in his buildings and drawings in the following years was interpreted as the effect of modernism, Gaudi's nature-oriented design approach has never been lost.

\section{Casa Battlo}

Casa Battlo, one of Antoni Gaudi's best-known buildings, was designed as a residence. The major share in the importance of this work, which is used as a museum, is not only the architect but also the brave owner who built this house.

In line with the request of the client Battlo family, Antoni Gaudi carried out the rehabilitation and facade reform of the building between 1904 and 1906. The architect carried out the facade reform with three main design elements. The first of these is the creation of a stone gallery with the columns left bare on the ground floor of the façade. The second is the continuation of these columns from the inside on the first floor and the continuation of columns and similar items with this bony structure in the other interior spaces. On this floor, the effect of the gallery on the lower floor has been increased by using glass on the façade. Third, the upper floor facades supported by metal balconies were created (Villanueva, 2020, p.119).

With these phases on the exterior, bones and skull image effects were created on the surface. These designs were not limited to the façade; With the demolition of the interior walls on the first floor, the lights were tried to be included in the interior spaces.

Due to the building's two façades and the need for light, large openings were created on the front façade, and a gallery overlooking the Passeig de Gràcia street was constructed thanks to the windows. Likewise, the windows on the rear façade extending to the ground and the large windows in the core let the sunlight in (Yakın, 2016, p.23). In addition, the space in the center of the plan was enlarged, allowing more daylight to enter (natural light was provided).

The majority of the façade is covered with broken mosaics and polychrome round ceramics, starting with a golden orange color and changing from aqua green to blue. This style is called Trencadís. Trencadis is the name given to the style of broken ceramic tile used in Catalan modernism. Technically and visually, it resembles French ceramic works called pique assiette. Trencadis is the name given to the composition that emerges by bringing together and detailing broken ceramic pieces, broken plates and dinnerware (Villanueva, 2020, p.119). 
One of the most distinctive and impressive elements of the façade is that the form forming the roof is actually a dragon's ridge and the tower next to it is constructed as St George's sword. In addition, at the end of the sword, there is a fourarmed cross covered with Majorcan ceramics, which symbolizes the holy family, and on it the Prophet. There are anagrams of Jesus, Mary and Joseph (Yakın, 2016, p.22).

The structure was named after one of the Catalan saints of the period, St. It describes the war between George and a dragon. Its tower in the form of a cone, stuck in the dragon's back, St. George's sword symbolizes Ascalon. The balustrades on the façade and the mouth forms on the hall façade symbolize the victims killed by the dragon and its own bones (Yakın, 2016, p.22).

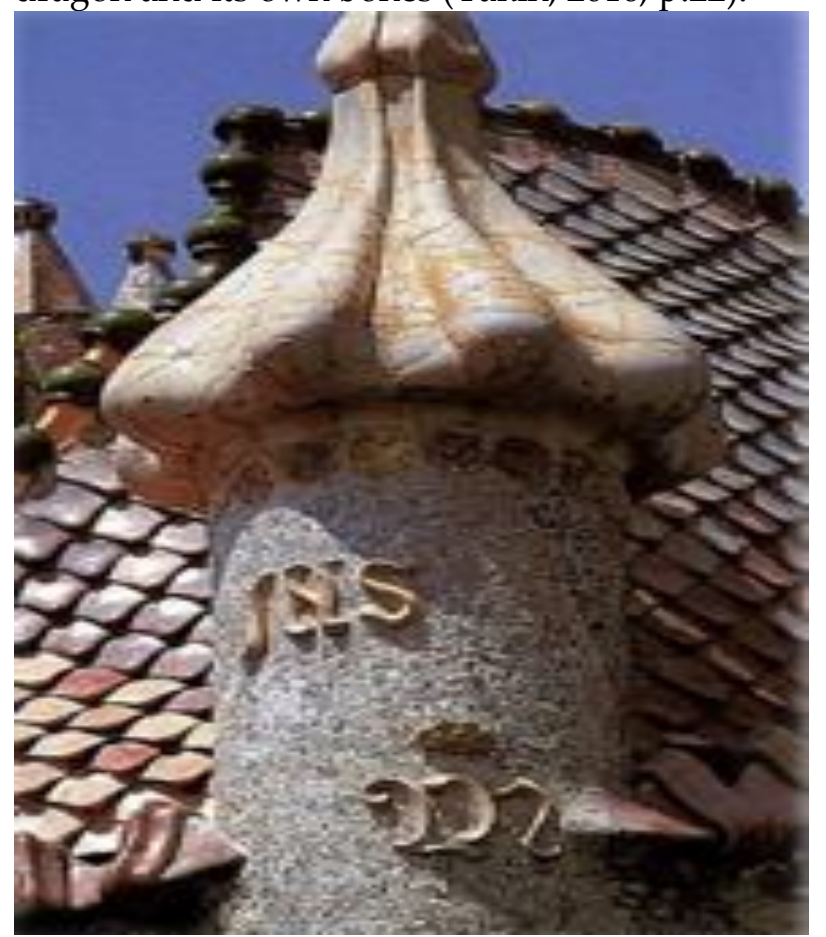

Figure 5. Casa Battlo chimney (Yakın, 2016, p.20)

This building, which was redesigned and arranged by Gaudi (1904-1906), was used by the Batllo family and for many years, it was purchased in the 1990s and restored faithfully to the original (Moreno, 2019, p.102). Until then, no one thought that such a world heritage site would be built at 43 Passeig de Gràcia street. But Gaudi and his assistants (Domènec Sugrañes i Gras, Josep Canaleta and Joan Rubió) finished the Casa dels ossos (House of Bones) between 1904 and 1906, and years later made it a symbol of Barcelona and almost a symbol of the Art Nouveau movement. Due to this reputation and original value, it expresses a passionate design approach to nature, Biophilia because it is one of the structures. Within the scope of the concept, the Casa Battlo structure is discussed (Moreno, 2019, p.102).

\section{Method}

In the study, 'biophilic design', which is examined within the scope of architecture, has a natureoriented content. Although the design approach has entered the literature in the last decade; It is assumed in this study that it was used in previous designs. With this assumption; The study was created by analysing a dwelling design of a wellknown architect. Antoni Gaudi's iconic Casa Battlo design is analysed in terms of biophilic design. In addition to the biophilic design principles, Semra Aydınlı's visual analysis methods in Architecture were also used in this study. The current state of Biophilic design elements is determined by literature research. To define it conceptually; The relationship between nature and humans is discussed within the framework of 'design'. Books, articles, theses and photographs were researched about the concept. Main titles related to the subject were indexed. Structure; was examined by obtaining information from observations and sources. The effects of biophilic design criteria in the Casa Battlo structure were analysed following spatial and visual examinations. The analyses are supported by the tables. In the tables using Kellert's (2015) biophilic design features; this building was examined for biophilic design features. With this method, the use of biophilic design in the building was determined. Descriptive analysis and document analysis methods are used from qualitative research methods.

\section{Analysis of Casa Batllo In Terms Of Biophilic Design}

Biophilic design concept has three phases. For this reason, the Casa Battlo structure is examined under three sub-headings in terms of biophilic design. 


\section{Direct experience of nature}

Concept of biophilia and biophilic design is defined previous contexts. The first phase of Biophilic design which is named 'Direct Experience of Nature' consists of eight subtitles: Light, Air, Water, Plants, Animals Weather, natural ecosystems, fire.

First headline of direct experience of nature is light. Taking natural light and get sunlight is a necessity for human health. An important part of human life is spent in closed areas and buildings. Variable lighting technologies are used in that indoors. Nevertheless, the necessity of sunlight goes on.

Having natural light at indoors is fundamental to human health and wellbeing. Natural light can assume aesthetically appealing shapes and forms through the creative interplay of light and shadow, diffuse and variable light, and the integration of light with spatial properties (Kellert \& Calabrese, 2015, p.12).

Gaudi should have thought that there was a great need for light because of the building had just two facades. So, he created large openings on both façades. However, it was not enough for him, so he expanded the skylight section. Thus, it provides natural light from the core of the building to the rooms, circulation areas and other spaces. The windows on both façades mostly expanded to go down to the ground.

Natural ventilation is important to human comfort and productivity. The experience of natural ventilation in the built environment can be enhanced by variations in airflow, temperature, humidity, and barometric pressure. These conditions can be achieved through access to the outside by such simple means as operable windows (Kellert \& Calabrese, 2015, p.12). While designing that building, wide openings and windows were used not only on the facades, but also on the surfaces opening to the courtyards and in the stairwell. The use of natural lighting and ventilation will also support the purpose of biophilic design in terms of energy efficiency.
Water is essential to life and its positive experience in the built environment can relieve stress, promote satisfaction, and enhance health and performance. The attraction to water can be especially pronounced when as-sociated with the multiple senses of sight, sound, touch, taste, and movement. Water in the built environment is often most pleas-ing when perceived as clean, in motion, and experienced through multiple senses (Kellert \& Calabrese, 2015, p.13).

It is known that an ornamental pool was used in the open courtyard in the first design of the building. The use of a building as a museum and the presence of human circulation in this building reveal certain limitations regarding design. It is thought that this water pool was cancelled for these reasons in the regulations made about twenty years ago.

The presence of plants can reduce stress, contribute to physical health, improve comfort, and enhance performance and productivity. The application of single or isolated plants, however, rarely exerts much beneficial effect (Kellert \& Calabrese, 2015, p.13).

In this building, which is used as a museum in its current state, it is seen that plants were used indoors in the old times when life continued. There are also plants in the courtyard.

An awareness and response to weather has been an essential feature of people's experience of nature throughout history, and critical to human fitness and survival. The perception of and contact with weather in the built environment can be both satisfying and stimulating. In biophilic Design views to the outside, operable windows, porches, decks, balconies, colonnades, pavilions, gardens, and more are necessities (Kellert \& Calabrese, 2015, p.13). An outdoor experience can be enjoyed in the organically shaped terrace area. Apart from this, the use of many windows and openings in the building provides air circulation.

Natural landscapes and ecosystems consist of interconnected plants, animals, water, soils, rocks, and geological forms. Also, the experience of fire can be both a source of comfort and anxiety (Kellert \& Calabrese, 2015, p.14). In this design, a fireplace is created. Not only was a fireplace created, but a 
seating area was created in order to feel the warmth of the fireplace in a semi-closed area.

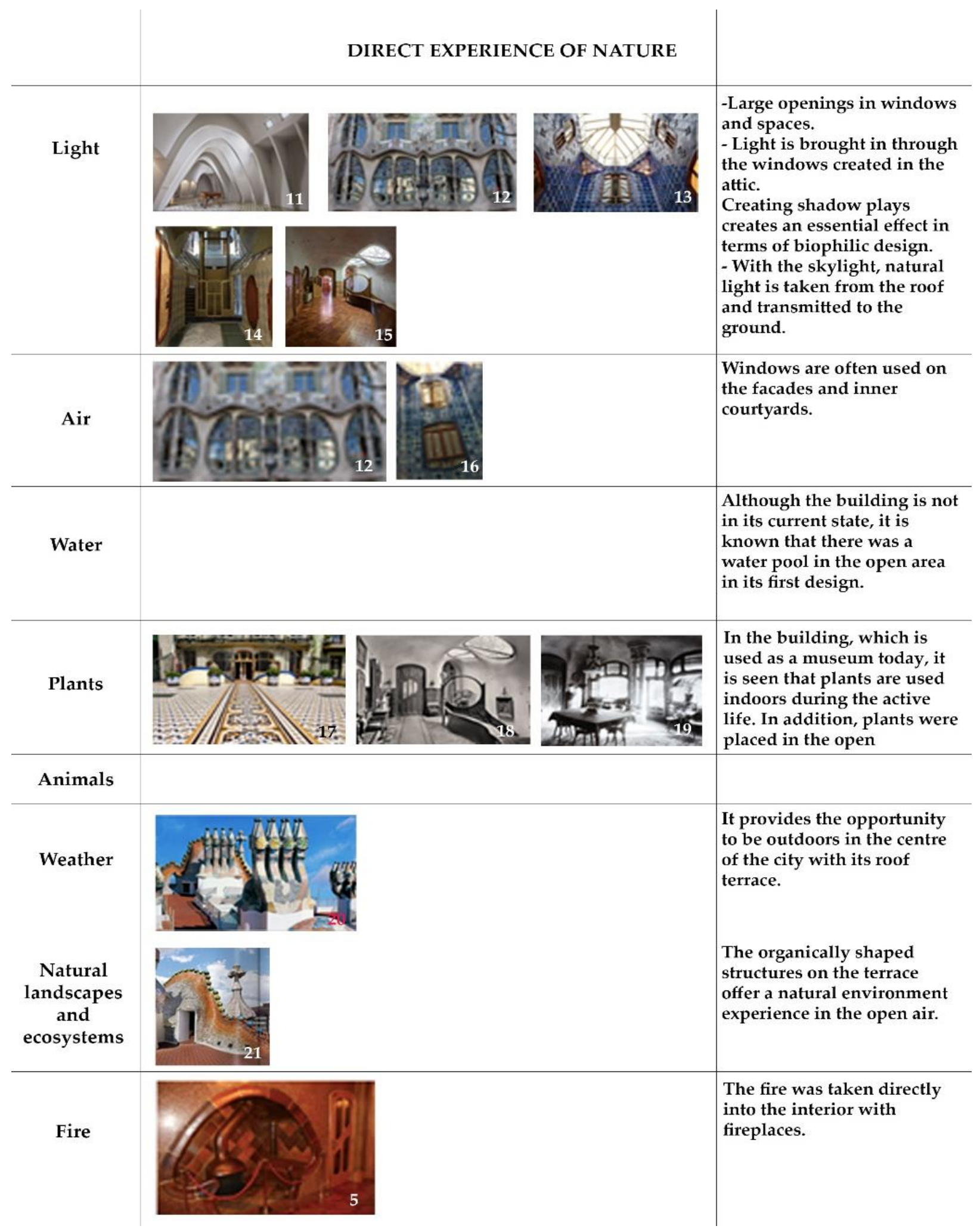

Figure 6. Direct experience of Nature 


\section{Indirect experience of nature}

The second phase of Biophilic design which is named 'Indirect Experience of Nature' consists of ten subtitles: Images of nature, natural materials, natural colors, simulating natural light and air, naturalistic forms, evoking nature, information richness, patina of time, natural geometries, biomimicry.

The image and representation of nature in the built environment (plants, animals, landscapes etc.) can occur by photographs, paintings, sculpture, murals (Kellert \& Calabrese, 2015, p.15). Gaudi used nature images and forms in a significant part of the building elements of the house he designed. For example, the end of chimney on the roof is in the form of a flower, the columns in the first floor are in the form of branches and leaves, and the roof surface is in the form of a dragon's back. They are just some of the representations of nature in that dwelling's design.

A stage of biophilic design is using natural materials. Stone, wood, cotton, leather, marble can be used in a wide array of products, furnishings, and other interior and exterior areas. When Casa Battlo was designed, natural materials were used on all surfaces. At the same time indoor equipment, furnitures are made from wood, stone and similar materials which found in nature.

The effective biophilic application of color should generally favor muted "earth" tones characteristic of soil, rock, and plants. The use of bright colors should be cautiously applied,

and emphasize such appealing environmental forms as flowers, sunsets and sunup's, rainbows, and certain plants and animals. Contrasting and pretentious colors should be avoided in natural designs (Kellert \& Calabrese, 2015, p.15).

The colors used in Casa Battlo cover the natural design so much that it is not possible to find a painting other than the material itself. wood and stone materials color the building with their natural color. Ceramic pieces on the façade and roof were used only from the colors of nature. Colors such as blue in the inner courtyard, nature scenery on the roof, and brown tones around the fireplace were preferred. Ceramics were applied from colors found in nature and other materials were used bare without being colored. It is seen that very bright and eye-catching colors are not preferred.

Artificial light can be designed to simulate the spectral and vibrant qualities of natural light in biophilic design (Kellert \& Calabrese, 2015, p.16). In this sense, the use of yellow lighting instead of white light can be given as an example in the nonilluminated sections of the building.

In line with this approach, which expresses the love for nature; forms and shapes of natural world may be charming. Natural forms were used throughout the building, including the ceilings. tree trunk or leaf forms were used in the columns. There are organic forms all over the building. It is not possible to find such a flat and inorganic form as drawn with a ruler.

The satisfying experience of nature can also be revealed through imaginative and fantastic depictions. These representations may not literally occur in nature, but still draw from design principles prominently encountered in the natural world.

At the same time the diversity and variability of the natural world is so pronounced, it has been described as the most information-rich environment people will ever encounter. Whether natural or built, people tend to respond positively to information-rich and diverse environments that present a wealth of options and opportunities, so long as the complexity is experienced in a coherent and legible way (Kellert \& Calabrese, 2015, p.16).

The building depicts the battle of a Catalan saint and a dragon. Its tower in the shape of a cone, stuck in the soldier's back, St. George's sword, Ascalon. The balustrades on the façade and the mouth forms on the hall façade symbolize the victims of the war and their own bones. By that description of building, it can be said that evoking nature and information richness parts of biophilic design is used exactly.

Change and a patina of time can be achieved through such design strategies as naturally aging materials, weathering, a sense of the passage of time, and in other ways (Kellert \& Calabrese, 2015, p.17). 
Since the building was renovated about 20 years ago, there is no trace of obsolescence in the building. It is not a very preferred situation due to its use as a museum.

Using Natural geometries in biophilic design refer to mathematical properties commonly encountered in nature (Kellert \& Calabrese, 2015, p.18). Many similar features were observed in this structure as well. One of the most obvious examples of this in house is the application of these mathematical geometries in ceiling layouts.

Biomimicry refers to forms and functions found in nature, especially among other species, whose properties have been adopted or suggest solutions to human needs and problems. ( (Kellert \& Calabrese, 2015, p.18) The use of the thick leather surface form on the roof is one of the examples of this structure.

\section{INDIRECT EXPERIENCE OF NATURE}

\begin{tabular}{|c|c|c|}
\hline $\begin{array}{l}\text { Images of } \\
\text { nature }\end{array}$ & $E$ & $\begin{array}{l}\text { Natural forms appear on the structure in various } \\
\text { ways. }\end{array}$ \\
\hline $\begin{array}{l}\text { Natural } \\
\text { materials }\end{array}$ & & $\begin{array}{l}\text { Natural materials have been used not only in } \\
\text { architecture but also in interior furnishings. }\end{array}$ \\
\hline $\begin{array}{l}\text { Natural } \\
\text { colors }\end{array}$ & & The colors of natural materials are used as they are. \\
\hline $\begin{array}{l}\text { Simulating } \\
\text { natural light } \\
\text { and air }\end{array}$ & & $\begin{array}{l}\text { Daylight effect is aimed by using yellow lighting } \\
\text { instead of white light in non-illuminated sections. }\end{array}$ \\
\hline $\begin{array}{c}\text { Naturalistic } \\
\text { shapes and } \\
\text { forms }\end{array}$ & & $\begin{array}{l}\text { Natural forms were used throughout the building, } \\
\text { including the ceilings. } \\
\text { It is not possible to find a flat and inorganic form as } \\
\text { drawn with a ruler. }\end{array}$ \\
\hline $\begin{array}{l}\text { Evoking } \\
\text { nature }\end{array}$ & & $\begin{array}{c}\text { Bone-shaped columns and bud-shaped chimneys } \\
\text { evoke nature. }\end{array}$ \\
\hline $\begin{array}{l}\text { Information } \\
\text { richness }\end{array}$ & 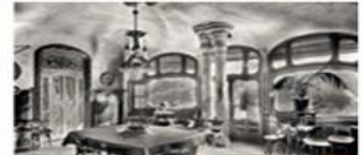 & $\begin{array}{l}\text { Interiors with different forms and textures. } \\
\text { In particular, this structure, together with the interior } \\
\text { furnishings and furniture, provides an interior } \\
\text { experience that creates a great variety. }\end{array}$ \\
\hline $\begin{array}{l}\text { Age, change, } \\
\text { and patina of } \\
\text { time }\end{array}$ & & $\begin{array}{c}\text { Although it is an old building, it is in good condition } \\
\text { with restorations. }\end{array}$ \\
\hline $\begin{array}{l}\text { Natural } \\
\text { geometrics }\end{array}$ & & Forms coming from nature are geometricized. \\
\hline
\end{tabular}

Figure 7. Indirect experience of Nature 
Concept of biophilia and biophilic design is defined previous contexts. The first phase of Biophilic design which is named 'Direct Experience of Nature' consists of eight subtitles: Light, Air, Water, Plants, Animals Weather, natural ecosystems, fire.

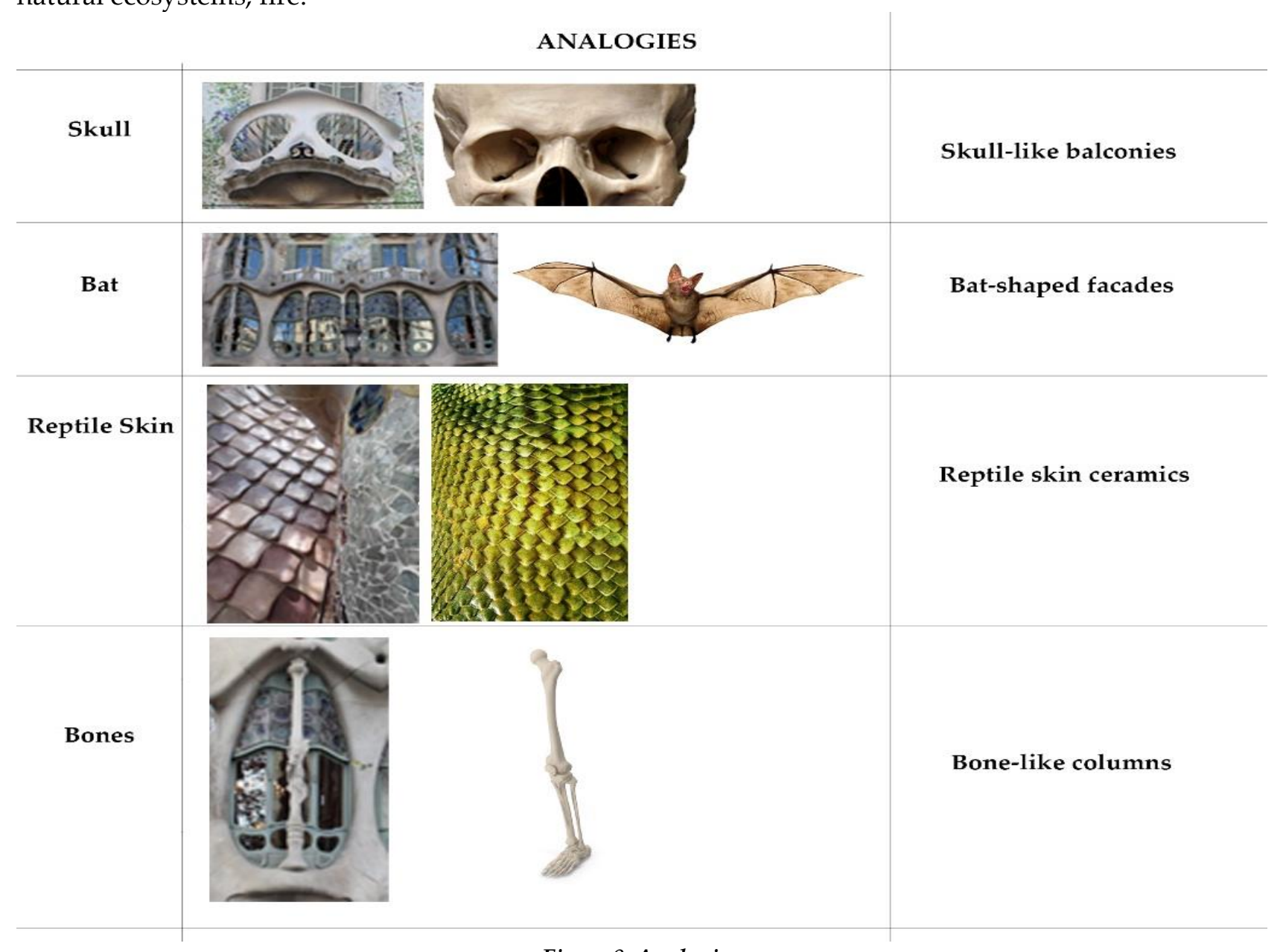

Figure 8. Analogies

There are some elements mixed with biomimicry in Gaudi's unique architectural understanding. Some forms that the architect takes from nature can cause analogical evaluations of the building. In this sense, analogical approaches are not related to biomimicry because they remain at the plastic level.

\section{Experience of Space and Place}

Humans evolved in adaptive response to the complementary benefits of prospect and refuge. Prospect refers to long views of surrounding settings that allow people to perceive both opportunities and dangers, while refuge provides sites of safety and security. biophilic outcome can be achieved through such design strategies as vistas to the outside, visual connections between interior spaces, and the occurrence of secure and sheltered settings (Kellert \& Calabrese, 2015, p.19).

Creating small balconies connecting the indoor and outdoor spaces, designing courtyards where you can spend time outdoors, and using the roof as a terrace overlooking the environment can be defined as the prospect and refugee subheading of biophilic design for Casa Battlo.

Complex spaces tend to be variable and diverse, while organized ones possess attributes of 
connection and coherence (Kellert \& Calabrese, 2015, p.19). Plan of the dwelling doesn't have a standard geometric shape. The rooms were created in a more complex way instead of being created with a sequential form. However, the fluency and luminosity of the circulation spaces and the stairs creates an order of its own within the complexity of this structure.

integration of space can be improved by a central focal point that arises either functionally or thematically (Kellert \& Calabrese, 2015, p.20). space integrations are seen in many buildings. However, the creation of spaces within the space in this structure also constitutes other different design aspects.

For example, a sitting area is designed for the fireplace, again at the foot of the fireplace in the room.
Successfully navigating a building often depends on clearly understood connections between rooms facilitated by clear and discernible transitions. (Kellert \& Calabrese, 2015, p.20). Corridors connecting different spaces to each other also look like the same in all rooms and interiors.

People's comfort and wellbeing often relies on freely moving between diverse and often complicated spaces. pathways and points of entry and egress are especially critical to fostering mobility and feelings of protection (Kellert \& Calabrese, 2015, p.20). In this structure, the width and spaciousness of the circulation areas facilitate the transitions between the spaces. In addition, planning the entrance area too big and bright compared to a house of this size provides confidence and comfort in terms of first impression.

\section{EXPERIENCE OF SPACE AND PLACE}

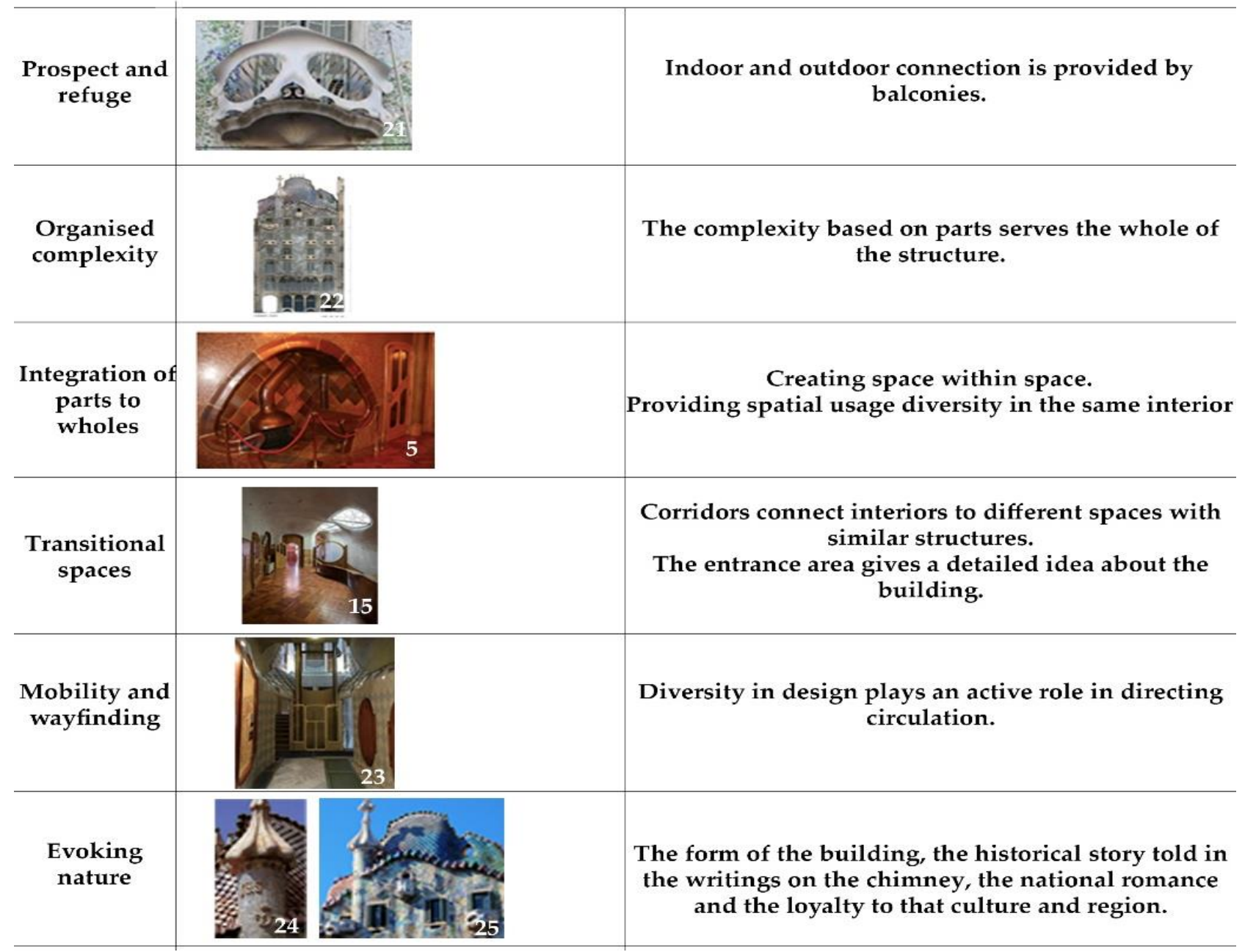

Figure 9. Experience of Space and Place 
An empathy for familiar places reflects this territorial feeling that can be enhanced by both cultural and ecological means. Culturally relevant designs promote a connection to place and the sense that a setting has a distinct human identity. (Kellert \& Calabrese, 2015, p.20). The choice of local materials in Casa Battlo and the fluent expression of a story (legend of Catalan Saint George and dragon) on the interior and exterior spaces and facades of the building clearly express the cultural and ecological connection of the building to its location. Cultural and ecological connections to buildings often stimulate people to conserve built environments.

\section{Discussion and Conclusions}

Mankind builds artificial environments for himself and still cannot break from nature. Although technology and industry develop; The effort to return to nature and ecological continues. Especially in the last century, the effort to return nature has revealed nature and ecology-focused design approaches. Although these approaches belong to the last century, they are a clear indication of the human's belonging to nature. Biophilic design has also recently been defined as one of the approaches that express human commitment to nature. The nature-oriented design approach is one of the design efforts of man since its existence. With this framework, the 'Casa Battlo' dwelling, which is one of the important cultural heritage and historical artifacts has been analysed and evaluated within the scope of the biophilic design approach. In the results obtained from spatial and visual analysis; It can be stated that the Casa Battlo structure has been created within the newly defined biophilic design approach. The designer of the building has a work beyond his time. A painter, architect or artist works in line with the currents up to his time. Or he creates a new trend by being influenced examples in history. This building has not been evaluated with the design concepts of the designer's own period, but within the framework of a design approach expressed approximately two centuries later. In this context, it can be stated that Gaudi made original works beyond his time.

Although he was involved movements such as art nouveau, modernism, it is possible to state that he has a valid design even for a design approach that emerged two centuries later. It seems that he is the architect of every era. Since the biophilic approach is today's concept, exemplary buildings are considered to be modern architectural buildings. Although the concept is new; It is seen that examples can be taken from the past. In other words, it may be possible to take not only modern biophilic designs but also historical buildings as examples for biophilic architectural design approach.

\section{References}

Antoniades, A.C. (1992). Poetics of architecture: theory of design. New York: Wiley Publishing.

Bayraktaroğlu, Ö.E. (2014). Mimarlikta ekosistem düşüncesiyle tasarlamak. (Yayımlanmamış doktora tezi). İstanbul Teknik Üniversitesi Fen Bilimleri Enstitüsü, İstanbul.

Bosch, M., Olona, J, Vargas, A., Villanueva, X., Villanueva, I, Atance, A. (2020) Master Plan of Gaudís Casa Batlló Management and documentation, ISSN: 1136-758-X, LOGGIA №33. (p.83\&89)

Dosde, D. (2016). The illustrated biography of Antoni Gaudi. Barcelona: Dos de arte ediciones.

Dosde, D. (2017). Casa battlo, The most orginal creation of Antoni Gaudi, ISBN:978-84-9103057-7. Barcelona: Dos de arte ediciones (p.29\&19)

Fromm, E. (1979). The heart of man: Its gentus for good and evil (Sevginin ve Şiddetin Kaynağı).Türkçe birinci basım, İstanbul: Payel Yayınları.

Geronimo, L.P. (2014). La Simbologia De Latlantida Motiu Dinspiracio De La Casa Battlo. Batxillerat, Jaume Genís Terri. (p.47-55)

Gündüz, E. (2019). Mimaride doğayı temel alan tasarım yaklaşımları izleği. İstanbul Teknik Üniversitesi, Fen Bilimleri Enstitüsü, İstanbul.

Heerwagen, J. \& Orians, G. (1993). Biophilia hypothesis. Washington: Island Press.

Hinojosa, S.C. (2018) The light well as element of luminous control inside the architectural spaces, case of study: Batlló House. Estoa, 7 , 1390-7263. 
Hinojosa, S.C. (2018) The light well as element of luminous control inside the architectural spaces, case of study: Batlló House. Estoa Vol. 7, 1390-7263.

http://mimdap.org/2014/11/bir-gaudi-harikasy-casabatllol (28.09.2021).

https://commons.wikimedia.org/wiki/File:Interior Casa B atll\%C3\%B3 (1927).jpg (28.09.2021).

https://www.archdaily.com/90689/ad-classics-casa-batlloantoni-gaudi (28.09.2021).

https://www.casabatllo.es/ (28.09.2021).

https://www.casabatllo.es/en/antoni-gaudi/casabatllo/inside/(28.09.2021).

https://www.terrapinbrightgreen.com/wpcontent/uploads/2015/11/Parkroyal CaseStudy.pdf (28.09.2021).

www.biophilic-design.com (28.09.2021).

Kellert, R. S. (2005). Building for life: Designing and understanding the humannature connection. Washington, DC: Island.

Kellert, S. R., (2008). Biophilic design: The theory, science, and practice of bringing buildings to life. New York: Wiley Print.

Kellert, S. R., Calabrese, E. (2015). The Practice of Biophilic Design, www.biophilicdesign.com, (p.3-21)

Md Rian, I. \& Sassone, M. (2014). Tree-inspired dendriforms and fractal-like branching structures in architecture: A brief historical overview. Frontiers Of Architectural Research, 3(3), 298-323.

Mirak, M. (2018). Die Synthese von ,Innen' und ,Außen' am Beispiel von Antoni Gaudís. Mietshaus Casa Batlló. Miradas, 4(1), 10-21.

Moreno, A. (2019). Casa Batlló, Tecrica Patrmoni, pg. 100-109, September 2019. (p.106)

Orr, D. W. (2002). The nature of design: Ecology, culture, and human intention. New York, NY: Oxford University Press.

Parlatır, İ., Gözaydın, Ne., Zülfikar, H., Belgin T., Türkmen, S., Yılmaz, Y. (1988). Türk Dil Kurumu Türkçe Sözlük I-II. Ankara: Türk Dil Kurumu Yayınları.

Ramzy, N. (2015). Biophilic qualities of historical architecture: In quest of the timeless terminologies of 'life' in architectural expression. Sustainable Cities and Society, 15, 42-56.

Rapoport, A. (1969) House from the culture. Englewood Cliffs, N.J.: Prentice Hall.
Roe, J. (2009). Antoni Gaudi. New York, USA: Parkstone Press International.

Schmidt, K. (2010). Göbekli Tepe - the Stone Age Sanctuaries.New results of ongoing excavations with a special focuson sculptures and high reliefs. Documenta Praehistorica, 37, 239-256.

Şenozan, M.I. (2018). Insan - mekan - doğa etkileşiminin sürdürebilir bir öğretisi olarak biyofilik tasarım. Yüksek Lisans Tezi. Mimar Sinan Güzel Sanatlar Üniversitesi, İstanbul.

Ünlü, E. (2017). Mimarlikta biyofili olgusu ve sağllk yapıları örneği. Yüksek Lisans Tezi. Gebze Teknik Üniversitesi, Gebze.

Villanueva, X., Olona,J. Iglesias-Campos, M.A., Bosch, M. Rosell, J.R. Navarro, A. Villanueva.I. (2020). Restoration of the main façade of Gaudís Casa Batlló. ISSN: 1136-758-X, LOGGIA №33. (p.118\&139)

Vitrivius. (2005). Mimarlık üzerine on kitap. Ankara: Şevki vanlı mimarlık vakfı yayınları.

Wilson, E. O., (1984). The biophilia hypothesis. Cambridge, MA: Harvard University Press.

Yakın, Y. (2016). A different approach to Antoni Gaudi's interior design in accordance with his architectural wording. Master thesis. Haliç Üniversitesi, Fen Bilimleri Enstitüsü, İstanbul. 